\title{
Role of the public and the media in civil court proceedings in DR Congo
}

\author{
Guy-Prosper Djuma Bilali Lokema*
}

\begin{abstract}
This article explores and exposes the role public and media play in civil court proceedings in Democratic Republic of Congo (DRC). These roles are examining at a moment of multiplication of international instruments of promotion and protection of human rights. This trend at international level coincides with a worldwide national movement of recognition of fundamental rights.

Whereas it is universally proclaimed that citizens have right to participate in public affairs of their state, this right also realizes in the judicial field. Traditionally, citizens can act as juror. But, this institution doesn't exist in DRC. They can, directly or indirectly, in some countries, participate in the election of judges and prosecutors. It is regrettable that this mode of designation of judges is not consecrated in DRC. It would be an efficient way for citizens to sanction those judges and magistrates who were accused of bribery, corruption, misappropriation, and abuse of authority.

Despite the negative view Congolese legislator has on public considering them as a disturbing factor, people can also act as activists of human rights in order to make better the functioning of some tribunals like the Constitutional Court of DRC and to force the observation of procedure before jurisdictions.

Media play important role in civil court proceeding in DRC. Media have access to courtroom on the basis of the publicity of hearings recognized by international treaties relative to human rights, by DRC Constitution of 18 February 2006 as modified and completed to date, and by other laws relative to proceedings to observe before Congolese jurisdictions.

Despite the publicity of hearings, the Act of 22 June 1996 fixing procedures of exercise of freedom of press prohibits the broadcasting of judicial trial without permission of judge presiding tribunal. But this Act is presently under consideration at Congolese Parliament. It is not excluded that the recent practice observed in some tribunals consisting to accept and tolerate broadcasting without formal authorization be consecrated by lawmakers. Media influence people on the view of judicial institutions and by providing information on tribunals and proceedings.
\end{abstract}

* The author is Barrister to Bar of Kinshasa/Gombe, Lecturer at School of Law, University of Kinshasa and member of Cerdia (Centre d'Etudes sur le Reglement de Différends Internationaux en Afrique [Centre of Studies on the Settlement of International Disputes in Africa] and of Creeda (Centre de Recherche et d'Etudes sur l'Etat de Droit en Afrique [Centre of Research and Studies on Rule of Law in Africa] in Democratic Republic of Congo. E-mail: pydjuma@yahoo.fr 


\section{Introduction}

Nowadays, the contemporary legal systems allow public to play a role in court proceedings. It can be a civil or criminal proceeding. This role can be determined by different proceeding laws or it can stem from the world realities. People can influence the progress of any proceeding. Some legislations provide the case of transfer of trial far from some places when security and normal functioning of trial can be disturbed by people.

In some other legal systems, people can be selected in order to sit at a jury which will sentence a case. The jury is admitted as well as at a civil or criminal trial. So, at a moment where human rights are on spotlight, and the role of civil society is strongly rising, it is interesting to cast a light on the role that public can play in civil court proceedings in Democratic Republic of Congo (DRC).

This analysis falls in a particular period where people are claiming an increasing participation of citizens in public affairs. It will be studied by considering the place of public in civil Court proceedings (A), in one hand, and the role of media in civil Court proceedings (B), in another hand.

\section{A. The place of public in civil court proceedings}

It is important to know what kind of role public can play in civil court proceedings. This question seems essential when we take into consideration the fact that in accordance with provisions of Universal Declaration of Human Rights and the most of national laws trial is opened to public except when the judge decides that hearing must be held in camera.

So, we will explore the traditional role public plays in civil court proceedings, in one hand (1). After this, we will analyze the particularity of Congolese legal system as of the place of public in civil court proceedings, in other hand (2).

\section{Classical role exercised by public in civil court proceedings}

Traditionally, public exercises three major roles in civil court proceedings. The first is to constitute jury (a) and the second concerns the direct participation in the election of judges and prosecutors (b), without omitting the indirect intervention in the designation of some judges in charge of civil proceedings (c).

The two first do not exist in DRC but not the third. 
a) Citizens are chosen to constitute jury

Many national laws like British, French, and American have put in place a system which permits citizens to be selected, according to some criteria predefined, and to sit as jurors. It is a citizenship participation in the rendering of justice ${ }^{1}$.

To sit as jury members requires to satisfy some conditions, among others to pay regularly his tax, to have a good behavior, to never have criminal conviction.

Even if jury is not recognized in $\mathrm{DRC}^{2}$, a judicial institution can be considered as a residue of the jury or another form of citizens'participation in judicial matters. Congolese Act on judicial organization and competences provides the possibility for some particular people to complete a seat of a tribunal, when this latter is examining a case implying the application of customary law of people of different origins.

This principle is completely applied when the case calling application of customary law is opposing people of different customs. In this case, the tribunal seat will be completed by two assessor judges, each one will represent one of the customs to be applied. The two assessor judges will sit aside a career judge, presiding the tribunal following the article 10 of Organic Act no. 13/011-B of 11 April 2013 on organization, functioning and competences of jurisdiction of judicial order ${ }^{3}$.

As announced, the jury is an exceptional example of citizens' participation in the public affairs. Many national laws and international treaties allow citizens to participate directly or indirectly in the governance of their States. The best and known way of this participation is the election. But modern democracies do not exclude the possibility for people to have a part in the conduct of public affairs. That is why several national laws and Constitutions foresee the organization of referendum in some matters already provided for in the fundamental texts or decided by political organs like the Government or the Parliament.

The Universal Declaration of Human Rights stipulates in its article 21, paragraph 1 that "everyone has the right to take part in the government of his country, directly or through

1 Read for example Shamena Answar, Patrick Bayer and Randi Hjalmarsson, "A fair and impartial Jury? The Role of Age in Jury Selection and Trial Outcomes", Economic Research Initiatives at Duke Working Paper Number 125, p. 10 and following in http://ssm.com (accessed on 6 December 2018).

2 Antoine Rubbens, Le pouvoir, l'organisation et la compétence judiciaires [The Power, the organization and judicial competences], Tome I, Bruxelles, Kinshasa, 1970, pp. 144-145.

3 According to this article 10 " The Tribunal of Peace seats at number of three judges in criminal mater, at single judge in civil matter. However, it seats at number of three judges when it applies local custom. In this case, two of three judges are notables of the place designated by the judge presiding the jurisdiction" (My own translation). 
freely chosen representatives". A similar clause exists in International Covenant on Political and Civil Rights ${ }^{4}$ and in African Charter on Human and Peoples Rights ${ }^{5}$.

According to these provisions and in accordance with internal texts, it is legally authorized to citizens to take part in management of public affairs. If eyes are generally fixed on political field, the participation of citizens also appears in judicial domain, mainly in the jury activities.

Legislative acts determine the conditions for a citizen to seat as juror. These conditions concern the conduct of individual in the society.

Unfortunately, as well as the Constitution and procedural laws of DRC have not foreseen the possibility for citizens of this country to seat as juror. Maybe the critics raised against the jury have pushed the legislator to not establish jury. They rebuke jury a number of misdeeds among others to confide justice in the hands of people who have any legal knowledge and practice of law, they are not professional in legal matters. They miss expertise in organization and functioning of judicial institutions. Recently, accusations of racism were made against jury ${ }^{6}$.

A part from the reasons presented against jury in the countries where this institution is recognized, some arguments can be used to justify the absence of jury in Congo. It can be supported that at the era of establishment of Congolese judicial system, at the end of nineteenth century and the beginning of twentieth century, the King Leopold II of Belgium, the private owner of Congo, faced the lack of judicial personnel, in one hand, and the existence of a population without education, in other hand.

Due to the fact that Congo was a private property of King Leopold II of Belgium, this kingdom refused to take part in the personal colonial adventure of its King. Facing this challenge, King Leopold II resorted to people of different nationalities other than Belgian in order to install his colonial administration. The most famous of his administrators was Henry Morton Stanley ${ }^{7}$. Belgium entered in the colonial sphere at the death of King Leopold II who bequeathed Congo ${ }^{8}$ to his country through his testament.

4 Following the article 25 of International Covenant on Political and Civil Rights « Every citizen shall have the right and opportunity, without unreasonable restrictions:

To take part in the conduct of public affairs, directly or through freely chosen representatives".

5 it is said at the article 13, paragraph 1 of African Charter on Human and Peoples Rights that "Every citizen shall have the right to participate freely in the government of his country directly or through freely chosen representatives in accordance with the provisions of the law".

6 Read Mark Israel, "Ethnic Bias in Jury Selection in Australia and New Zealand", International Journal of the Sociology of Law, No. 26, 1998, pp 37-38; Samuel R. Sommers, "On Racial Diversity and Group Decision Making: Identifying Multiple Effects of Racial Composition on Jury Deliberations", Journal of Personality and Social Psychology, Vol. 90, No. 4, 2006, 597-612 p.

7 Consult with interest J. Stengers, "Stanley, Léopold II et l'Angleterre" [Stanley, Leopold II and England] in Le Flambeau, No.4, 1954, 378-386 p.

8 Mandjumba Mwanyimi-Mbomba, Chronologie générale de l'histoire du Zaïre (Des origines à 1988)

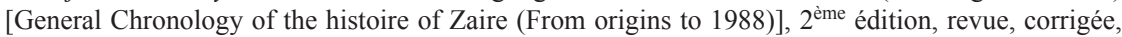
augmentée, Kinshasa, 1989, p. 53. 
In this context of lack of judicial personnel, it should be a big mistake to use, at the same time, the colony financial resources to recruit judges and magistrates through Europe, and to establish a jury. It is important to remember that at the beginning of colonization of Congo, there were few European people living and working in this country. European people had not only a treatment different than African people but also the jurisdictions specialized in cases involving white people. Black people had the special Tribunals. So, there was a separation regime between Europeans and Africans even in the framework of organs in charge to settle disputes 9 .

Even though traditional African justice has experimented by African societies before the colonization ${ }^{10}$, African people were not associated to the administration of colonial justice. Certainly, it could be an error to associate African people to colonial justice because this latter had a main goal to sit domination and oppression of Belgian occupier over Congolese territory ${ }^{11}$. So, the participation of African population in colonial administration should have no other justification than complicity to European barbary ${ }^{12}$. It also supposes that colonialist had a minimum of consideration of local indigenous. That was not the case.

Whereas Belgian colonialist tried to transform black people, better to assimilate them and their civilization to European one, it was then impossible to give responsibility to people whose the process of assimilation was not yet finished.

Visibly, even if the lack of education ${ }^{13}$ and the default of assimilation of African people to colonialist's civilization, especially his legal system, can be presented as one of reasons of the inexistence of jury in Belgian colonial system settled in Congo, the true reason can be found elsewhere in the consideration given to autochthons.

9 Mandjumba Mwanyimi-Mbomba, op. cit, p.29.

10 See for example Matadi Nenga, a Congolese jurist who does not hesitate to magnify African traditional justice system prior the beginning of the Belgian colonization of Congo relatively to the respect of principle of publicity of trial. Matadi Nenga Gamanda, Droit judiciaire privé [Private Judicial Law], Louvain-La-Neuve, 2006, p. 128.

11 See Georges Nzongola-Ntalaja, Faillite de la gouvernance et crise de la construction nationale au Congo-Kinshasa. Une analyse des luttes pour la démocratie et la souveraineté nationale [Bankruptcy of the governance and crisis of the national construction in Congo-Kinshasa. An analysis of struggles for democracy and national sovereingty], Kinshasa-Montréal-Washington, 2015, p. 43 and following; Isidore Ndaywel è Nziem, Histoire générale du Congo. De l'héritage ancien à la République Démocratique [General History of Congo. From former heritage to Democratic Republic], Paris-Bruxelles, 1998, p. 271 and following; Colette Braeckman, Vers la deuxième indépendance du Congo [Toward the second independence of Congo], Bruxelles-Kinshasa, p. 9 and following.

12 African people had opposed a strong resistance to European occupation of Africa's lands. See Georges Nzongola-Ntalaja, op. cit., p. 55 and following, Isidore Ndaywel è Nziem, op. cit., p. 298 and following.

13 Congolese citizens could not have a high degree of instruction similar to European one which could allow them to play an important social role like to sit as a juror due to the lack of academic teachings. The first University in the country, Universite de Lovanium and later rebaptized Université de Kinshasa, was founded in 1954. 6 little years before the independence of Congo. Read Isidore Ndaywel è Nziem, op. cit., p. 504 and following. 
The jury supposes the participation of citizens in the administration of State affairs ${ }^{14}$. However, autochthons were not considered as citizens, their human being was recalled into question. King Leopold II was accused of worse crimes against local population. His administration put in place a sanguinary regime of atrocities known as "red rubber". It has consisted in cutting hands, legs and breasts to people who were not able to realize the quota or a maximum quantity of rubber imposed to them by the colonial agents ${ }^{15}$.

Even if the existence of assessor judges should be viewed as a form of citizens' participation in judicial matters or a residue of African traditional justice, this participation in civil court proceedings tends to disappear, because there is an effort of standardization between customary law, unwritten law and modern law, written one. This process has been formalized by the enactment of Act of 1 August 1987 relative to family code, in one hand, and the interbreeding of Congolese cultures and customs mainly in the big cities, in one other hand.

Participation of citizens in judicial matters also takes form by the election of judges and prosecutors in some countries.

b) Citizens are directly participating in the election of judges and prosecutors

Some national laws allow citizens to participate directly in the designation of judges and prosecutors by the channel of elections. Some views were presented against election for nominating judges and prosecutors. Professor Ntumba Luaba ${ }^{16}$ does not share this opinion. Personally, I have proposed to use election as a mode of designation of members of prosecutor office of Constitutional Court of DRC ${ }^{17}$.

In this country, the election as a mode of nomination of judges and prosecutors is not consecrated by Congolese laws. However, this mode would be a good way for citizens to punish these judges and prosecutors who are practicing corruption ${ }^{18}$, bribery, misappropria-

14 They can consider a true participation of Congolese citizens to the administration of public affairs of their State only in 1958, after the first elections organized by the colonial power. Read Isidore Ndaywel è Nziem, op. cit., p. 524 and following.

15 Adam Hochschild, King Leopold's Ghost: A Story of Greed, Terror, and Heroism in Colonial Africa, Boston-New York, 1998, 405 p; Isidore Ndaywel è Nziem, op. cit., p.333 and followings; Colette Braeckman, op. cit., p. 12 and following; Mandjumba Mwanyimi-Mbomba, op. cit., p. 53; Daniel Vangroenweghe, Du sang sur les lianes. Léopold II et son Congo [The Blood on the lianas. Leopold II and his Congo], Bruxelles, 1986, 318 p.

16 Ntumba Luaba Lumu, Droit constitutionnel général [General Constitutional Law], Kinshasa, 2007, p. 321

17 Read Djuma Bilali Lokema Guy-Prosper, « Le Parquet général près la Cour Constitutionnelle de la République Démocratique du Congo " [The General Prosecutor's Office near the Constitutional Court of Democratic Republic of Congo], Congolese Yearbook of Constitutional Justice, Vol. 1, 2016, pp.96-97.

18 See for example Muzong Kodi, Corruption et gouvernance en République Démocratique du Congo durant la transition (2003-2006) [Corruption and Governance in Democratic Republic of Congo during the transition (2003-2006)], Tshwane (Pretoria), 2008, p. 5-25. The author retraces the historical of corruption in DRC since the birth of this country up to now. 
tion, abuse of authority, etc. It would also be the way to evacuate these corrupted judges and magistrates from Congolese judicial system. A kind of sweep in the yard.

The judicial practice in DRC reveals many cases of lack of justice mainly when judges and prosecutors commit crimes mentioned above. Some sentences are falsified by erroneous motivation made by judges in order to favor a camp in detriment of another one. Because the party favored has corrupted the judges or is attached to these latter by the family relationship. In other cases, the judges have decided to charge someone by misappropriation or abuse of authority.

Unfortunately, the lack of rule of law in many domains in DRC maintains this kind of disorder combined with the default of punishment against those who perpetrate these infringements.

The misfortune of Congolese population comes from the fact that political system keeps this impunity and gives-up citizens without protection ${ }^{19}$. The best thing Congolese people should wish is to stop this lack of sanction at every level. Then, as political leaders are not interested in the idea to listen citizens and to punish or to encourage tribunals to sanction people who are perpetrators of the infractions indicated above, it should be interesting to people themselves to punish these corrupted judicial actors through elections.

However, it is supposed to have an independent and impartial body which should organize elections and publish poll in accordance with the willing of voters ${ }^{20}$. In this case, with the poll, citizens should sanction and clean up judiciary field from judges and prosecutors unworthy to exercise public tasks of prosecuting and judging.

People can also intervene indirectly in the nomination of judges and prosecutors

19 In case of bribery, corruption, misappropriation and abuse of authority, Congolese legal system provides to lodge a complaint against those judges or prosecutors in accordance with article 55 and following of Organic Act No. 13/010 of 19 February 2013 relative to proceedings before the Court of Cassation. It is not sure to obtain sanctions against Judges or magistrates accused of corruption, deny of justice, or abuse of authority due to the interference of factors other than legal and due to solidarity between judges and magistrates. In practice, this proceeding is avoided or not often exploited by practitioners, because when a Barrister is identified and indexed as a trigger of sanction mechanism against judges and magistrates, he should be sanctioned by judges with negative sentences against his clients. That is why some Barristers abstain themselves to trigger suits against judges and prosecutors.

20 Democratic Republic of Congo is known as a theater of electoral disputes. The third cycle of elections of 2018 is marked, as the two first (2006 and 2011), by the requirement of truth of ballot boxes because, unfortunately, the willing of citizens was turned away. According to many testimonies, the loser was proclaimed elect at the place of winner. Read Marcel Wetsh'okonda Koso and Balingene Kahombo, Le pari du respect de la vérité des urnes en Afrique. Analyse des élections présidentielles et législatives du 28 novembre 2011 en République Démocratique du Congo [The Challenge of Respect of the Truth of Ballot Boxes in Africa. Analysis of Presidential and Parliamentary Elections of 28 November 2011 in Democratic Republic of Congo], Bruxelles, 2014, $302 \mathrm{p}$. 
c) Indirect intervention in the nomination of judges

Many legal systems submit some nominations at a high level to a parliamentary vote. For instance, the designation of several members of executive in USA must be approved by the Senate.

Speaking of judicial area, the Senate launches investigations on the proposed candidates to occupy a post of a high level. The recent case has concerned the appointment of Honor Kavanaugh as judge at US Supreme Court. Unquestionably, the intervention of Senate in view to confirm the appointment of people proposed by US President corresponds not only to the constitutional prerogatives of this high chamber but also to indirect participation of citizens in public affairs.

Why is this process considered as a kind of citizens' participation in civil court proceedings?

It is not complicated to build a bridge between the Senate intervention in the course of nomination of judges of US Supreme Court and civil court proceedings. Judges are important actors of proceedings and the channels by which they reach their posts in the high Court or in an ordinary Court or Tribunal has incontestably a positive or a negative impact in the implementation of laws in general and laws relative to proceedings in particular.

Can you imagine in particular context of African countries how the appointment of high magistrates or judges may influence the settlement of disputes in the political area? Two cases coming from DRC can be done as example.

In 2006, on the eve of first general democratic elections after the independence of the country $^{21}$, the DRC President of this time, Joseph Kabila, has appointed several judges at the Supreme Court of DRC. This nomination could appear neutral but it is very important to remember that according to both DRC Constitution and electoral Act of DRC, this high Court has mission to settle presidential electoral dispute. Some months later, the poll of the second round of presidential election has risen electoral dispute between the challenger, the former warlord Jean-Pierre Bemba, and the outgoing President, Joseph Kabila.

According to article 74 of the electoral Act of $\mathrm{DRC}^{22}$, the Constitutional Court has the heavy charge to judge presidential electoral dispute and to declare the final result of presi-

21 Democratic Republic of Congo, former Zaire, has experimented presidential elections notably with alone candidate, President Mobutu after the coup of 24 November 1965. Zairean citizens had no choice among several challengers. These elections were not considered as democratic. A Congolese constitutionalist does not hesitate to speak of monarchic institutions towards political organs at the time of President Mobutu. Read Ambroise Kamukuny Mukinay, Droit constitutionnel Congolais [Congolese Constitutional Law), Kinshasa, 2011, p.334.

22 The article 74 of Electoral Act of DRC as modified and completed to date provides that « the competent jurisdictions to hear electoral dispute are:

1. The Constitutional Court, for the presidential and legislative elections..." (the own translation of the author) 
dential election in accordance with the article $72^{23}$ of electoral Act of DRC as modified and completed to date. In other words, the Independent and National Electoral Commission of DRC announces the provisional results ${ }^{24}$ of election which are submitted to the Constitutional Court. This latter has power to reject the results provided by the Independent and National Electoral Commission or to confirm by making them a definitive one.

Who have the duty to hear electoral dispute of presidential election? Of course, the members of Supreme Court. Then, the appointment of new judges was incontestably a strategic way to anticipate and to counter the prospective attempt of destabilization of president's power by using legal means.

It was not a surprise after the second round of presidential election that the challenger, the former warlord, Jean-Pierre Bemba went to the DRC Supreme Court which has been playing the role of Constitutional Court, when this latter was not installed yet, and lodged complaint against the result proclaimed by the Independent and National Electoral Commission. This dispute has given place to one important case-law in the field of electoral $l^{25}$. Even though several jurists have observed that the lawyers of Jean-Pierre Bemba have failed to their professional duty, the sentence of the Court in Bemba's case was not astonishing. Mass was already said.

That is why after the presidential election of 2011, the challenger of Joseph Kabila, Etienne Tshisekedi Wa Mulumba, the historical leader of Congolese opposition, refused to bring electoral dispute before the DRC Supreme Court. He has explained his attitude by the mistrust he had in a Court whose members are appointed by President Joseph Kabila and acquired to the cause of this latter. The position of the major opponent against Kabila's regime was a refusal to the calling of the archbishop of Kinshasa, Cardinal Laurent Monsengwo. This archbishop claimed the truth of ballot boxes ${ }^{26}$ and encouraged opposition leaders to seize the high Court for electoral dispute. The calling of archbishop of Kinshasa was heard by another opposition leader, Vital Kamerhe who has seized the Court for electoral dispute. Similar to Bemba case in 2007, the Court has rejected action introduced by opponent Vital Kamerhe ${ }^{27}$.

What is the particularity of Congolese legal system?

23 The first paragraph of article 72 of the DRC Electoral Act as modified and completed to date indicates that "The Constitutional Court proclaims the final results of presidential election within two days following the expiration of recourse period, if any recourse has not been laid down before it" (Translation is mine)

24 Article 2 of the DRC Electoral Act as modified and completed to date.

25 See Judgment of 27 November 2007, RCE PR 009, Case Mouvement de Libération Nationale (MLC) v. CEI, Bulletin des arrêts de la Cour suprême de Justice, numéro spécial, contentieux électoraux 2006-2007 [Supreme Court Judgment Report, Special Issue, Electoral Disputes], p. 89 and following.

26 See Marcel Wetsh'okonda Koso and Balingene Kahombo, op. cit., p. 202 and following; Pamphile Mabiala Mantuba-Ngoma, op.cit., p. 128.

27 CSJ, 16/12/2011, RCE 011/PR Union pour la Nation Congolaise (UNC)[Union for Congolese Nation]v.Joseph Kabila, Bulletin des Arrêts [Judgment Report], 2014, p. 100. 


\section{Particularity of Congolese legal system}

The Congolese judicial system allows citizens to access freely to some informations relative to cases pending before Tribunals and Courts ${ }^{28}$. Some jurisdictions have website where citizens can get informations on hearings calendar, on the cases which will be called and the date scheduled for verdict.

Generally, these informations are obtained at registrar office. But, due to the theft or the loss of some important pieces of procedure contained in the files, free access to tribunal files has been restricted. It is only limited to the litigants concerned by the disputes. This precaution is also taken in order to protect parties in the trial because these informations may concern their intimacy, personal data or properties which cannot be divulged in the society. Then, when parties have access to the tribunal files, they must be under surveillance of one registrar office member ${ }^{29}$.

Pressure is made on justice administration for providing citizens access to main informations relate to cases examined by judicial institutions. This effort is praiseworthy but the particular context of judicial affairs in DRC is not favorable to this system. There are many sensibilities around judicial cases that it is careful to not hurry the advent of this new system. Projections are made to instore reforms in judicial sector which will include more access to informations relative to cases settled by tribunals and to cases pending before them.

In a country like $\mathrm{DRC}$, it is not easy, even for the practitioners, to access to decisions rendered by Court and tribunals. It exists a publication of decisions of the former DRC Supreme Court in the Bulletin des Arrêts ${ }^{30}$, a wonderful effort made by a special service of Ministry of Justice. Unfortunately, this Judgment Report is not regular. The practitioners must extend their research of jurisprudence on other sources ${ }^{31}$.

Out of Judgment Report of the former DRC Supreme Court, there is also the publication of judgments of DRC Constitutional Court in official Journal of DRC. If the official Journal $^{32}$ of DRC is regularly published, the issue containing the judgments of DRC Constitutional Court is not. Then, free access to case-law remains an objective to reach. The efforts continue to be made in order to make citizens really informed of decisions rendered by Congolese Tribunals and Courts. Despite this, public is seen as a disturbing factor.

28 See Rubbens Antoine, Le droit judiciaire congolais. La procédure judiciaire contentieuse du droit privé [The Congolese Judicial Law. Contentious Procedure of Private Law], T. I, Bruxelles-Kinshasa, 1978, pp. 201-202

29 Mukadi Bonyi and Katuala Kaba Kashala, Procédure civile, Kinshasa, 1999. p.9

30 Judgment Report (My own translation)

31 Mukadi Bonyi and Katuala Kaba Kashala, op. cit, p. 10.

32 Article 94 of Organic Act No. 13/26 of 15 October 2013 relative to organization and functioning of Constitutional Court. 
a) Legislative negative view on public

The public taken not as a whole of citizens but as a crowd is considered negatively in the laws relative to judicial organization. According to article 60 of DRC Organic Act No. 13/011-B of 11 April 2013 on organization, functioning and competences of jurisdictions of judicial order, a High Court may refer a case from a lower tribunal of its territorial jurisdiction to another of the same rank located in the same territorial jurisdiction for public safety and legitimate suspicion ${ }^{33}$.

Unlike situation of legitimate suspicion which presupposes fear on the partiality of judges or tribunal ${ }^{34}$, the referral for reasons of public safety generally relates cases of public troubles created by a crowd. A major author has written that "le climat social et politique d'un lieu ou d'une région peut être détérioré au point qu'il ne soit pas possible de juger certains faits ou certaines personnes dans la sérénité requise pour rendre bonne justice, soit que les juges y subissent des pressions intolérables, soit que des désordres soient à craindre autour du prétoire $»^{35}$.

So, when they may fear public troubles or disorders caused by the crowd which can disturb the normal functioning of a tribunal, it is possible to refer a case from a tribunal to another. This competence belongs to the prosecutor. In this case, tribunal may judge disputes outside its ordinary seat. Article 45 of Organic Act on organization, functioning and competences of jurisdictions of judicial order already quoted provides the possibility for a tribunal to have a fairground audience outside of its administrative seat.

Unfortunately, Congolese history has recorded some situations where the citizens had played a negative role confirming fear expressed about eventual public troubles that crowd may cause. In 2006, in the framework of presidential electoral dispute ${ }^{36}$, the trial was seriously and gravely disturbed by the supporters of Jean-Pierre Bemba, challenger of the outgoing DRC President Joseph Kabila who had been proclaimed as winner of presidential election. The militants of Mouvement de Libération du Congo (MLC), political party of Mr.

33 The French original text is written as follows « Le Tribunal de Grande Instance peut, pour cause de sûreté publique ou de suspicion légitime, renvoyer la connaissance d'une affaire, d'un Tribunal de Paix de son ressort à un autre Tribunal de Paix du même ressort.

La Cour d'appel peut, pour les mêmes causes, renvoyer la connaissance d'une affaire d'un Tribunal de Grande Instance de son ressort à un autre Tribunal de Grande Instance du même ressort.

La Cour de cassation peut, pour les mêmes causes, renvoyer la connaissance d'une affaire d'une Cour d'appel à une autre ou d'une juridiction du ressort d'une Cour d'appel à une juridiction de même rang du ressort d'une autre Cour d'appel ».

34 Read Gabriel Amissi Ngumbi Muloba, Les parties au procès en matière de renvoi de juridiction pour cause de suspicion légitime [Parties to trial in matter of referral of jurisdiction in case of lawful suspicion], Kinshasa, 2018, 126 p.

35 Rubbens Antoine, Le pouvoir, l'organisation et la compétence judiciaires [The judicial power, organization and competences], Tome I, Bruxelles, Kinshasa, 1970, p. 253.

36 Judgment RCE PR 009 of 27 November 2006 Mouvement de Libération du Congo [Movement for Liberation of Congo v. Cei, DRC Supreme Court, Report of Judgment, Special Issue, Electoral disputes 2006-2007, p. 89 and following. 
Bemba, had notably fired subsidiary premises of DRC Supreme Court. Therefore, decision was taken to outsource the trial ${ }^{37}$.

Despite the situation of public troubles created by the citizens, these latter may also act as human rights activists in favor of a good functioning of justice institutions. It must be noted that this optimal functioning has a positive impact on the respect of proceedings.

b) Citizens acting as human rights activists in the process of nomination of judges

It is a general principle recognized by the major international instruments of human rights that citizens have to participate in the administration of public affairs ${ }^{38}$. This participation may take several forms ${ }^{39}$. People do not hesitate to organize demonstrations in order to influence a decision one important state organ is about to take. Protestations can aim to express the citizens' opinion ${ }^{40}$.

This situation has been put in the spotlight at the occasion of tertiary renewal of seat of Constitutional Court of DRC. According to paragraphs 3 and 4 of the article 158 of DRC Constitution of 18 February 2006 as modified and completed to date, the mandate of Constitutional Court member is of 9 years non-renewable. The Constitutional Court is renewed by third every three years. However, at each renewal, it will proceed to the draw of member by group" 41 . This clause of DRC Constitution is not very clear because it submits every renewal to the organization of draw. Fortunately, this lack of clarity was resolved by the Organic Act No.13/026 relative to the organization and functioning of Constitutional Court. The second paragraph of article 6 of this Organic Act provides that "The Constitutional Court is renewed by third every three years. During the first two renewals, it will proceed to the draw of outgoing member by group for the members initially designated" 42 . The article 7 of Organic Act gives the period of substitution of member of the Court. It must be done a month early or a week later before the expiration of mandate.

However, while both DRC Constitution and Organic Act quoted fix a time of 3 years to renew the seat of Constitutional Court by drawing a judge by the three groups composing the Court who will have to leave the High Court and to be replaced by three other, some resistances appeared. The question seemed to be ignored by the institutions involved in the

37 See Rigobert Minani Bihuza, 1990-2007, 17 ans de transition politique et perspectives démocratiques en République Démocratique du Congo [1990-2007, 17 years of Political Transition and Democratic Perspectives in Democratic Republic of Congo], Kinshasa, 2008, p. 109: Pamphile Mabiala Mantuba-Ngoma, Les élections dans l'histoire politique de la République Démocratique du Congo (1957-2011) [The Elections in the Political History of Democratic Republic of Congo], p. 75 and following.

38 Article 21 of Universal Declaration of Human Rights, article 25 of International Covenant on Civil and Political Rights, article 13 of African Charter on Human and Peoples Rights.

39 Directly or indirectly by his representatives.

40 Today, we can take the case of yellow vest in France.

41 My own translation.

42 My own translation. 
replacement of the three judges called to leave the DRC Constitutional Court. It has been observed a similar behavior from members of the Court. Because, in accordance with article 116 of the Organic Act relative to the organization and functioning of Constitutional Court, the term of mandate of judges who will be drawn to leave the Court will be exceptionally for three and six years instead of 9 years provided ordinarily for the members of the Court. The second paragraph of this latter article invests the Chief registrar in power to organize the draw in a public hearing following a procedure laid down by the Organic Act.

In front of this silence and this lethargy scheduled, a group of civil society members composed of NGO acting in Human Rights law and Justice sectors begun an important work of sensitization through social media, publishing, radio and TV stations. This campaign for the renewal of the seat of Constitutional Court was extremely noisy, striking, and successful to the point that the Government has decided to call all institutions implying in the process of renewal of the seat of Constitutional Court to take all necessary precautions in order to comply with the DRC Constitution and the Organic Act quoted.

The goal sought is to reach a better functioning of DRC Constitutional Court. Because an irregular seat should become a cause of blocking of this High Court and of other public organs which need, in their functioning, advice and interpretations of law made by the Constitutional Court. An irregular and illegal seat cannot settle any dispute. This negative situation represents a danger for the functioning of DRC political organs and for the electoral process due to the key role DRC Constitutional Court is called to play. Electoral process, already in danger given the delay in the organization of elections scheduled for the end of 2016, should suffer of it. Risks of crisis, political tensions, and of destabilization of DRC and its neighbors should rise and amplify worries about future of States of Great Lakes region.

Unfortunately, despite this wonderful involvement of citizens, the process of tertiary renewal of Constitutional Court did not follow the tract established by the law. A natural event came and disturbed the process. A judge, Yvon Kalonda Kele Oma, died just before the organization of draw and for unclear reasons, two judges among who had seemed to keep some independence vis-à-vis the executive resigned. So, it became useless to organizing draw because according to the DRC Constitution and Organic Act, three judges could have to leave the High Court and by the concurrence of circumstances, three had left it. Then, to organize draw became unnecessary. This view is contradicted by the prominent jurists who think that the death and the resignation of two members of Constitutional Court should not lead to the violation of DRC Constitution. Because, according to this fundamental law, the draw has to be organized.

The role played by the organizations of civil society, like the Centre de Recherches et d'Etudes sur l'Etat de Droit en Afrique (CREEDA) [Center of Researches and Studies on Rule of Law in Africa] which has used social media, broadcasting program on radio and TV stations is an anticipation of the role that media can play in civil court proceedings. 


\section{B. The role of media in civil court proceedings}

The modernization of our societies is accompanied by the transformation of lives and by the growing place that media occupy in daily activities. If some past years, the mass media were limited to radio, television and newspapers, today the technical means have accelerated the number of mass media including internet, social media which concentrate and gather more people than whatever else media.

People can try to estimate the impact of media on the practice of law, in this specific case, on a civil court proceedings? Do media play a role in civil court proceedings in DRC? This country is very big. Some people call it a sub-continent due to its immensity but there is also a strong concentration of population around big cities, especially around Kinshasa, the capital city, which gathers more than 50 local television and radio stations. ${ }^{43}$ With this increasing number of television stations for a population estimated about 15 millions of people, more than the whole population of some African countries like Burundi ${ }^{44}$, CongoBrazzaville $^{45}$, Gabon, Rwanda, etc.

The role media play in civil court proceedings will be analyzed through the publicity of hearing, the broadcasting of judicial hearings with permission of judge presiding Court and through the influence of media specialized in legal matters have on the citizens.

\section{a) The publicity of hearing}

The media access to the courtyard or to the courtroom has a basic foundation coming from international instruments of promotion and protection of Human Rights at international level, and from many DRC laws relative to the judicial organization and to press freedom and other laws concerning the exercise of journalism activities.

DRC doesn't live disconnected from other countries. It participates in international legal business. So, it has concluded and ratified some international treaties which impose the public character of trial. This is a sign of fair trial ${ }^{46}$. Amid these international conventions,

43 Pamphile Mabiala Mantuba-Ngoma, op. cit., p. 75; Jean-Pierre Lifoli, « Médias, instance de régulation et élections en République Démocratique du Congo »[Media, Regulatory Body and Elections in Democratic Republic of Congo], in Elikia M'Bokolo (dir.), Elections démocratiques en République Démocratique du Congo. Dynamiques et perspectives [Democratic Elections in Democratic Republic of Congo. Dynamics and Perspectives], Kinshasa, p. 104.

44 According to website of Foreign Affairs Ministry of Republic of Burundi, this latter has 11.5 millions of people. See https:/www.mae.gov.bi/en/2018/06/24/burundi-localisation/ (Consulted on 10 March 2019)

45 The nearest neighbor of DRC, Congo-Brazzaville, has a population estimated at 4,04 millions of people. See http:/www.ambacongo-us.org/fr-fr/lecongo/populationetculture/populationducongo.as px (Consulted on 10 March 2019).

46 You may read a book written by a Congolese jurist, Matadi Nenga Gamanda, Le droit à un procès equitable [Right to Fair Trial], Kinshasa, Louvain-la-Neuve, 2002. 
it can be mentioned the Universal Declaration of Human Rights ${ }^{47}$, the International Covenant on Political and Civil Rights ${ }^{48}$, and African Charter of Human and People Rights $^{49}$.

At domestic level, the first place belongs to the DRC Constitution of 18 February 2006 as modified and completed to date. The article 20 of the fundamental law of DRC states the principle of public hearings of courts and tribunals $\mathrm{s}^{50}$. The provisions with this similar content also exist in the article 14 of Organic Act No.13/010 of 19 February 2013 relative to the procedure before the Court of Cassation and in the article 91 of Organic Act relative to the organization and functioning of Constitutional Court.

Then, the fact to plan and impose that the hearings of Courts and Tribunals will be open is the basis of media access into the courtroom. This opens the possibility to cover and broadcast a judicial event taking place inside Justice Palace. Journalists or ordinary citizens, of course people interested in the cases examined by the judges, are free to attend a trial, to make a report for other people using all tools legally authorized. It can be mentioned photos, videos, audio, caricature, stenography, internet, social media, newspapers, television broadcasting. It is not different with system put in work in Russia ${ }^{51}$.

There is no problem for a report made after the trial but the difficult rises for a direct retransmission. In some cases, a permission is required, in some other it is unnecessary to be authorized to cover a trial unfolding before a Tribunal.

47 According to article 10 of Universal Declaration of Human Rights "Everyone is entitled in full equality to a fair and public hearing by an independent and impartial tribunal in the determination of his rights and obligations and of any criminal charge against him".

48 The article 14 paragraph 1 of International Covenant on Political and Civil Rights provides "All persons shall be equal before the courts and tribunals. In the determination of any criminal charge against him, or of his rights and obligations in a suit at law, everyone shall be entitled to a fair and public hearing by a competent, independent and impartial tribunal established by law. The Press and the public may be excluded from all or part of a trial for reasons of morals, public order (ordre public) or national security in a democratic society, or when the interest of the private lives of the parties so requires, or to the extent strictly necessary in the opinion of the court in special circumstances where publicity would prejudice the interests of justice; but any judgement rendered in a criminal case or in a suit at law shall be made public except where the interest of juvenile persons otherwise requires or the proceedings concern matrimonial disputes or the guardianship of children".

49 See article 7 of African Charter on Human and Peoples Rights.

50 It is specially written « The hearings of Courts and Tribunals are open, unless this publicity be considered dangerous for public order and morality. In this case, the tribunal can order a closed session"(My translation)

51 See Andrei Richter, "Court Reporting by Audiovisual and Online Media in the Russian Federation”, European Audiovisual Observatory, 2014, p. 13. 


\section{b) The broadcasting of judicial hearings with permission}

It is extremely important in the framework of this study to make a difference between legal provisions relative to live retransmission of trial and the recent practice in this field. It is also crucial to underline that system of permission laid down by 1996 Act fixing procedures of exercise of press freedom ${ }^{52}$ seems to involve toward a new system providing more freedom to press organs to cover and make a live retransmission without authorization.

This 1996 Act is in the midst of redesign at Congolese Parliament in view to replace it by a new one, well adapted to the requirement of modernization and to more advanced democratization in DRC.

Congolese Act of 1996 fixing procedures of exercise of freedom of press is a reaction of Congolese society to dictatorship of Marshal Mobutu, former President of DRC, at the time of Zaïre. Mobutu's regime was characterized by the lack of fundamental freedoms, including press freedom.

The openness in favor of democracy came with the important address made by the President Mobutu on 24 April 1990. By this speech, President Mobutu abolished party-state and instituted multiparty system. This openness had an impact on citizens' basic rights and freedoms. Political and social forces of DRC had rooted up the convening of an important national forum called "Conférence Nationale Souveraine" 53 . This national forum opened the era of exercise of public freedoms and fundamental rights by a lot of people gathered at the same place. It broke and dissipated fear people had of Mobutu who has considered as a $\operatorname{god}^{54}$.

The 1996 Act fixing procedures of exercise of freedom of press abolished the monopoly of press organs, mainly in the domain of radio and television stations ${ }^{55}$. From now on, after several years of dictatorship and lack of press freedom, it has become possible to control media. Individuals other than Congolese government can create, manage, and control media out of governmental sphere.

For the first time after many decades, they have instituted the liberty of creation of media organs and the principle of plurality ${ }^{56}$ of media organs. They have thought that media can be controlled by everybody. Given that media can express economic, political, religious, and cultural opinions, it has proclaimed and encouraged the creation of radio and

52 The article 79 of Act No 96-002 of 22 June 1996 fixing procedures of exercise of freedom of press "At the risk of falling under the infraction to the present Act, it is prohibited:

To publish indictments and all other acts of judicial procedure before they had been read at a public hearing.

53 See Isidore Ndaywel è Nziem, op. cit, pp. 772-783.

54 This reality is strongly underlined in a famous television documentary dedicated to the reign and the fall of Marshal Mobutu. Thierry Michel, Mobutu, roi du Zaïre [Mobutu, King of Zaire].

55 Article 14 "The creation and the management of communication means of press companies, these agencies of press and messaging, in the same way than printing house and book stores are free. These activities are exercising in complete independence, in respect of law".

56 Articles 51, 52 and 53 of the 1996 Act fixing procedures of exercise of freedom of press. 
television stations, and newspapers ${ }^{57}$, by observing administrative process of declaration ${ }^{58}$ and by paying fees related to ${ }^{59}$.

The plurality ${ }^{60}$ of media organs is a guarantee of exercise of press freedom and liberty of opinion, in one hand, but also a way to develop a diversity of opinions because each media broadcasts the views and thoughts of people who control it which expresses a point of view different of a governmental position.

In the framework of the 1996 Act fixing procedures of exercise of freedom of press, in respect of presumption of innocence ${ }^{61}$, it is not authorized to broadcast hearings without permission of judge presiding of Court or Tribunal ${ }^{62}$. It is prohibited, and it can lead to lawsuit $^{63}$, the fact to make a live retransmission or to broadcast trial hearings without authorization ${ }^{64}$. It is very important to remember that this prohibition applies to criminal cases in consideration of legal words used by 1996 Act quoted. it is not excluded to extent the said prohibition to civil proceeding.

However, recent practice reveals a reverse direction taken by Court and Tribunal concerning the broadcasting of judicial activities, especially the broadcasting of hearings.

Some events are at the origin of this new orientation. First of all, it is good to remember that at the time of the enactment of Act relative to press freedom, in 1996, DRC had a bit access into internet, many people had not a simple email address. Social media were not enough developed and the exercise of press freedom and other fundamental freedoms were at their beginnings. Today, we are experimenting boom of these tools. Logically, it is not a surprise that a new practice rises.

These factors are outside judicial field. There are other factors taking birth at the functioning of Courts and Tribunals which justify the new trend. The installation of Commercial Tribunal and Labor Tribunal triggers the necessary proximity between judicial organs and media. Citizens have to be informed of existence and functioning of these new Tribunals.

So, it was imperative to communicate and to inform people in which cases and matters they can use new jurisdictions. It was necessary to organize seminars, workshops, and

57 See article 14 of the 1996 Act fixing procedures of exercise of freedom of press.

58 See articles 22 and 56 of Act No. 96-002 of 22 June 1996 fixing procedures of exercise of freedom of press.

59 Article 54 of Act No. 96-002 of 22 June 1996 fixing procedures of exercise of freedom of press.

60 Articles 51, 52, and 53 of Act No. 96-002 of 22 June 1996 fixing procedures of exercise of freedom of press.

61 Article 17 paragraph 9 of DRC Constitution; article 11 paragraph 1 of Universal Declaration of Human Rights; article 14 paragraph 2 of International Covenant on civil and political rights, and article 7 paragraph 2 of African charter on Human and Peoples Rights.

62 Article 79 paragraph e) of Act No. 96-002 of 22 June 1996 fixing procedures of exercise of freedom of press.

63 See Charles Mushizi, Les infractions de presse. Régime de répression et options de réformes [The infractions of Press. Repression Regime and Reform Options], Kinshasa, 2012, 189 p.

64 This authorization is required because the broadcasting can be an attempt of personal right of image, of private data, except when the interested parties consent to the broadcasting of their image. 
broadcasting explaining rules and proceedings. Then, invitations were sent to media organs to cover trial and make a live retransmission of some important hearings.

It is interesting not to forget that a trial report can be made using a large spectrum of tools: photos, stenography, caricature, email, etc. In this context, the permission to cover trial hearing seems unnecessary because the goal pursued is to diffuse Tribunal activities. Then, where it was compulsory to get a written permission from judge presiding the Court or Tribunals to cover hearings, and where it was imperative for judge presiding Court or Tribunal to ground his decision giving or refusing authorization to broadcast or to make a live retransmission on television channel, it is become optional to follow a compulsory proceeding in view to get this permission or to motive a giving or refusing permission to media organs to cover trial ${ }^{65}$.

This new trend would be confirmed or made explicit by the new Act fixing procedures of exercise of freedom of press under consideration in Congolese Parliament. The media have also a strong influence on the perception people have of justice.

\section{c) The influence of media specialized in judicial matters on the citizens}

The massive development of media organs ${ }^{66}$ in DRC pushes some of them to diversify their activities and then, to devote some of them to judicial or legal sector. Despite some abus$\mathrm{es}^{67}$, these media essentially play two roles. The first is pedagogic, the second is to raise up or create vocation in judicial or legal domain

The pedagogic role appears through many aspects in the context of DRC. It is interesting to focus attention on the protection and exercise of fundamental freedoms. In this case, freedom of speech deserves to be underlined. People of DRC who have lived during the period of Conférence nationale Souveraine ${ }^{68}$ were marked by the legal knowledge and the eloquence of Professor Marcel-Antoine Lihau Eboa ${ }^{69}$ who chaired the Constitutional Commission which was in charge to elaborate a democratic Constitution to replace the dictatori-

65 This recent trend was explained and confirmed notably by the judge presiding Labour Tribunal of Kinshasa/Limete.

66 See for example, Pamphile Mabiala Mantuba-Ngoma, op. cit., pp.74-75, Jean-Pierre Lifoli, op. cit, p.104.

67 Read Emiphe Munganga Cishugi, "Les violations récurrentes des droits de l'homme par les medias congolais: cas des émissions "Kin Makamba et Emission ya babola » [Recurrent Violations of Human Rights by Congolese Media: Case of Broadcasting « Kin Makamba" and Broadcasting ya babola], in Revue du Barreau de Kinshasa/Gombe, Kinshasa, No. 07/2005, pp. 170-174.

68 Precious informations on Conférence Nationale Souveraine can be found in Isidore Ndaywel è Nziem, op. cit., pp.772-783; Télesphore Muhindo Malonga, Droit constitutionnel et institutions politiques. Théorie générale et droit constitutionnel congolais [Constitutional Law and Political Institutions. General Theory and Congolese Constitutional Law], Butembo, 2009, p.470 and following

69 See Bula-Bula Sayeman (ed.), Pour l'épanouissement de la pensée juridique congolaise. Liber Amicorum Marcel-Antoine Lihau [For the Blooming of Congolese Legal Thought. Liber Amicorum Marcel-Antoine Lihau], Bruxelles, Kinshasa, 2006, pp. XVIII-XXXIV. 
al Zairean Constitution of $1967^{70}$. Professor Marcel Lihau and some other opposition leaders in DRC like Etienne Tshisekedi, at the time of Zaire, have created the first opposition party, Union pour la Démocratie et le Progrès Social [Union for Democracy and Social Progress](UDPS) against Mobutu's regime. The two leaders quoted who were among 13 Parliament Members ${ }^{71}$ have bequeathed to the Congolese nation the spirit of struggle against dictatorship.

Today, DRC is more advanced in terms of promotion and exercise of political rights. This country is seeking economic development and growth. It was not a surprise to see people of this country to struggle victoriously against the willing of the former President Joseph Kabila to run for a third presidential mandate ${ }^{72}$ while the 2006 DRC Constitution prohibits the possibility to get a third mandate ${ }^{73}$ because it limits to two presidential terms $^{74}$.

This tradition of struggle was used for example when it was question for citizens of DRC to claim the implementation of rules of law relative to tertiary renewal of seat of DRC Constitutional Court. The exercise of freedom of speech has impact on the civil proceedings.

The media raise people vocation in the field of legal and judicial sector. It is good to specify impact some lawyers or judges had on many generations. Judge Falcone and Andoni Di Pietro are quoted as example. These Italian jurists who have launched "clean hands operation" in Italy were the inspiration of many people who have decided to study and to practice law with a wonderful ideal to fight against injustice and impunity.

Media organs are conveying the ideal of justice and encouraging citizens to have confidence on national institutions, especially judicial. They help people to get information on the existence of prospective proceedings and on the way to use them. The broadcasting organized in the context of installation of Commercial tribunal and Labor tribunal had among others goal to encourage people to settle their disputes before specialized jurisdictions. It is good not to lose the view that modern society bans private revenge. It is not necessary to prohibit private revenge when citizens don't know which tribunal to address and which proceedings to trigger.

70 This Constitution of the second Republic was amended several times that some specialists think that all these amendments have instituted different Republic.

71 Isidore Ndaywel è Nziem, op. cit, p.759 and following.

72 The attempt for third mandate was supported in constitutional doctrine by Professor Evariste Boshab, a former DRC minister and prominent member of ruling political party. He has proposed to amend DRC 2006 Constitution of 18 February, even in its locked provisions by a double amendment. Read Evariste Boshab, Entre la révision de la Constitution et l'inanition de la nation [Between Amendment of Constitution and the Starvation of the Nation], Bruxelles, 2013, pp.327 and following.

73 Article 220 of DRC 2006 Constitution of 18 February 2006 as modified and completed to date.

74 Article 70 paragraph 1 of DRC 2006 Constitution of 18 February 2006 as modified and completed to date. 


\section{Conclusion}

Today, nobody can contest role both public and media can play in civil court proceedings in Democratic Republic of Congo. If, specifically speaking, the place of public in a civil proceedings seems to stagnate, despite some social changes, the role of media is continually evolutive. No-one can predict the future evolution because it depends on the progress of technology.

Nowadays, we have a multiplicity of social media and we ignore the invention of tomorrow. Then, one thing is sure the place of media in civil proceeding is tributary of the evolution of science and technology. It is a common thought among jurists that fact precede the law and some other prefer to say "necessity makes law".

It is very important in the context of this article to underline important role played by media during the transition period in $\mathrm{DRC}^{75}$. You know for example that with the advent of urban criminality, some people believed that there was the law of jungle in DRC, that criminals cannot be judged and sentenced. This popular belief was a sign of destruction of Congolese society. Then, the public authorities had resorted media to provide a reverse idea to this one largely expanded of impunity of some criminals.

The decision was to organize fairground audience in the site where the criminals called "Kuluna"were arrested. These trials were largely covered by media and broadcasted by many radio and television stations. It is true that it was in the field of penal law but we cannot deny its pedagogic dimension. These hearings had helped to restore confidence people have on Congolese jurisdictions.

After the general elections of 30 December 2018, people were waiting Mr Fayulu who has claimed to be the winner to bring the case before the Constitutional Court in order to be declared definitively winner. The decision of Constitutional Court in disfavor of Mr Fayulu did not push population to organize demonstrations. Many reasons can be presented to explain this attitude. Incontestably, the respect of judicial institutions led people to consider that Mr Fayulu has to accept the sentence rendered by the High Court of DRC.

Two cases are used. In 2006, Mr Bemba brought the case before the Supreme Court of $\mathrm{DRC}^{76}$. This latter rejected Bemba's claim. The former vice-President made a public statement recognizing the Court verdict. In 2011, Mr. Etienne Tshisekedi has refused to bring his case before the High Court because he thought that any objective decision could come from this Court but he has continued to claim his victory.

75 This period runs from the historical address of President Mobutu of 24 April 1990 to the accession to power of President Joseph Kabila after general elections of 2011. In practice, when people are using "transition", they refer to period prior the takeover by President Laurent-Désiré Kabila in 1997.

76 Judgment of 27 November 2007, RCE PR 009, Case Mouvement de Libération Nationale (MLC) v. Cei, Bulletin des Arrêts de la Cour suprême de Justice, numéro spécial, contentieux électoraux 2006-2007 [Supreme Court Judgment Report, Special Issue, Electoral Disputes], p. 89 and following. 
Media are playing an increasing role in Congolese society and in the civil court proceedings. It is crucial to adapt the Congolese law to the evolution of media. This is a charge of lawmakers. 